DOI: 10.1515/LPTS-2015-0010

\title{
PROSPECTS FOR USE OF SYNCHRONOUS RELUCTANCE MOTORS IN LOW-POWER ELECTRICAL DEVICES
}

\author{
J. Dirba, L. Lavrinovicha, R. Dobriyan \\ Riga Technical University, \\ 12/1 Azenes Str., Riga, LV-1048, LATVIA \\ e-mail: janis.dirba@rtu.lv
}

\begin{abstract}
This paper focuses on studying the synchronous reluctance motors as an alternative to low-power commutator motors. Analysis is done for the improved design of synchronous reluctance motor with a segmental external rotor. Relevant equations and a suitable method are proposed for calculating characteristics of the synchronous reluctance motors operating in a specific mode with electronic commutation as switched reluctance motors. It is concluded that synchronous reluctance motors in this mode can provide a wide range of characteristics and are quite competitive with commutator motors used in low-power devices.
\end{abstract}

Keywords: magnetostatic field, mechanic characteristics, switched reluctance motor, synchronous reluctance motor.

\section{INTRODUCTION}

Electrical motor is a highly important component of the electrical devices widely used in technical industries, including low-power electrical devices, for example, electrical appliances and power tools.

As of now, the most widely spread motors in low-power electrical devices are the commutator motors $[1,2]$. Despite the positive aspects of commutator motors, they still have serious disadvantages caused by commutators and brushes. Usually, commutator motors are made as high-speed, low-torque devices; this is the reason why such a motor is used with a transmission device, which, in turn, has its own disadvantages. This reduces the total safety and durability of electrical devices with commutator motors.

Brushless synchronous motors (BSMs) are quite a good alternative for commutator motors used in low-power electrical devices $[3,4]$. Depending on the application requirements, BSMs can be designed both with internal and external rotor. External rotor motors can be directly connected to the active part of device, which allows getting rid of transmission elements, thus improving the device safety and sizes. 
Recently, BSMs, especially those with external rotor, have rapidly replaced the commutator motors in such low-power electrical devices as different type fans, washing machines, medical equipment, computer devices, etc. [5, 6].

Now, when the use of BSMs in low-power devices is becoming more and more widespread, the question arises as to their production cost. The point is that these motors are normally used with permanent magnet excitation; however, even though prices of permanent magnets have decreased lately, these are still much higher than those of electrical steel. This is the reason for paying attention to synchronous reluctance motors (SynRMs) due to their safety and low cost of production.

The main objective of this work was to study the prospects for using SynRM as an alternative to the commutator motors in low-power electrical devices.

\section{DESIGNS OF SYNCHRONOUS RELUCTANCE MOTOR}

The SynRMs have neither excitation coils nor permanent magnets; this operating principle is based on variation in the magnetic flux due to different reluctance on its way. The SynRM electromagnetic torque is described by the equation [7]:

$$
T_{e m}=\frac{p \cdot m \cdot U^{2}}{2 \cdot \omega} \cdot\left(\frac{1}{x_{q}}-\frac{1}{x_{d}}\right) \cdot \sin 2 \theta,
$$

where $p$ is the number of pole pairs;

$m$ is the number of phases;

$U$ is the phase voltage;

$\omega$ is the angular frequency of armature current;

$x_{d}$ is the direct axis synchronous reactance;

$x_{q}$ is the quadrature axis synchronous reactance;

$\theta$ is the load angle between the supply voltage and the fundamental harmonic of no-load EMF.

From this equation it follows that the electromagnetic torque is mainly affected by the difference between $x_{d}$ and $x_{q}$ values. The higher the $x_{d} x_{q}$ ratio, the higher the SynRM electromagnetic torque. This is the reason why the rotor design is so important for a reluctance motor. Depending on the potential usage field, a specific rotor design has to be selected in order to achieve the maximum efficiency.

Different rotor designs of a four-pole SynRM are shown in Fig. 1.

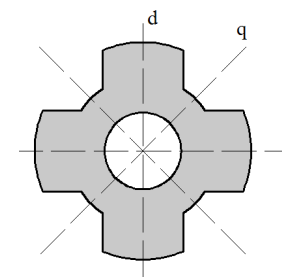

(a)

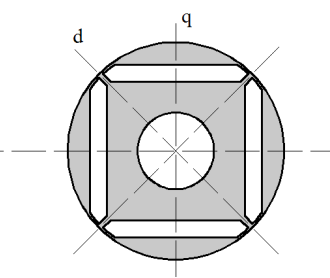

(b)

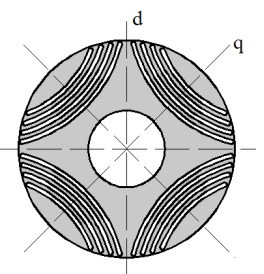

(c)

Fig. 1. Rotor designs of a four-pole SynRM:

(a) salient-pole rotor; (b), (c) rotor types with magnetic flux barriers. 
The SynRM rotor design shown in Fig. $1 a$ is a salient-pole rotor whose poles are magnetically connected via ferromagnetic yoke. This type of rotor can be made of electrical steel sheets or solid ferromagnetic material. In the former case, an additional caged starting winding is placed on the rotor; in the latter case (with a ferromagnetic rotor), there is no need for starting windings due to eddy currents which execute the starting winding function. The magnetic asymmetry of SynRM rotor (Fig. 1b,c) is achieved using specially formed non-magnetic gaps in the rotor that serve as barriers for magnetic flux reducing its quadrature component.

Nowadays, numerous rotor designs exist for SynRM with complex magnetic flux barriers which provide a high $x_{d} x_{q}$ ratio. For example, there is a known rotor design of SynRM with specific magnetic flux barriers providing the $x_{d} / x_{q}$ ratio up to 7-8 [8]. However, the more complex shape of magnetic flux barriers in the rotor of SynRM, the higher its production cost.

The SynRM having external rotor with salient poles is widely used due to its safety and simple production. The design of a two-pole SynRM with salient-pole external rotor is shown in Fig. 2a. This design includes two poles 1, 2, which are magnetically connected via external massive ferromagnetic yoke 3 . Usually, these motors have the pole coverage ratio in the range $0.5-0.65$. Stator 4 with $m$-phase winding 5 in its slots is stationary mounted on shaft 6 .

Despite the simplicity and operational safety of external rotor SynRM, the electromagnetic torque per unit volume of this motor is not high due to its massive ferromagnetic yoke, which increases the total motor size.

In order to increase the electromagnetic torque of SynRM, a new motor design with external rotor is developed (Fig. 2b), whose rotor is made of segmental ferromagnetic cores separated from one another by a non-magnetic gap [9]. In this case, the pole coverage ratio increases up to 0.8-0.98. Removing the ferromagnetic yoke from the design enables reducing the outer diameter of motor; besides, a specifically shaped rotor provides $30-40 \%$ increase in the electromagnetic torque per unit volume.

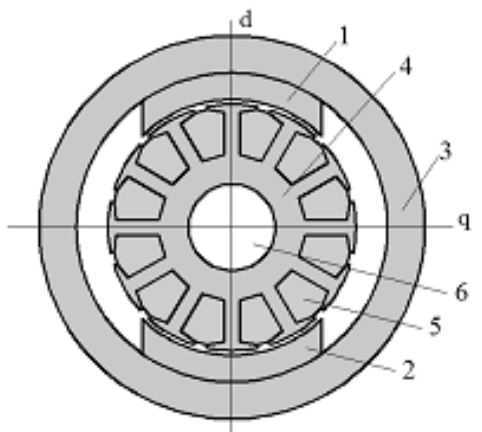

(a)

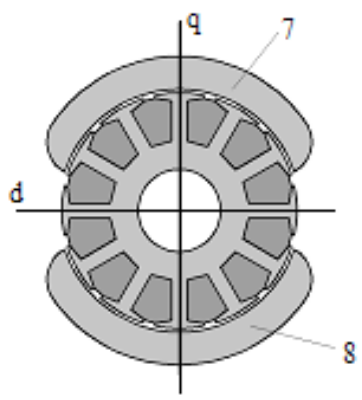

(b)

Fig. 2. Designs of two-pole SynRM with external rotor:

1, 2 - rotor salient poles; 3 - ferromagnetic yoke; 4 - stator; 5 - armature winding; 6 - shaft;

7, 8 - ferromagnetic segmental cores.

The design of SynRM with external rotor shown in Fig. $2 b$ is also safe and simple. In order to reduce electromagnetic torque ripples, the gap between ferromagnetic 
segments is to be equal to the width of stator slot opening. A more effective reduction in the torque ripples can be achieved through skewing the rotor segments by one stator tooth pitch [10]. However, in this case the electromagnetic torque significantly decreases due to the high value of demagnetized quadrature magnetic field. In order to decrease the influence of this field on the motor operation, it is recommended to use specifically shaped non-magnetic gaps in the middle of each rotor segment along the quadrature axis of the rotor.

\section{PROTOTYPE OF SYNCHRONOUS RELUCTANCE MOTOR WITH EXTERNAL ROTOR}

The developed design of SynRM prototype with external rotor is shown in Fig. 3. Its rated parameters are: $P_{N}=1 \mathrm{~kW}, n_{N}=3000$ RPM.

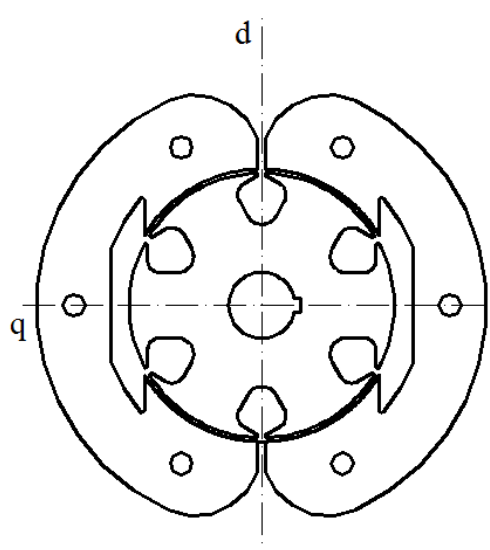

(a)

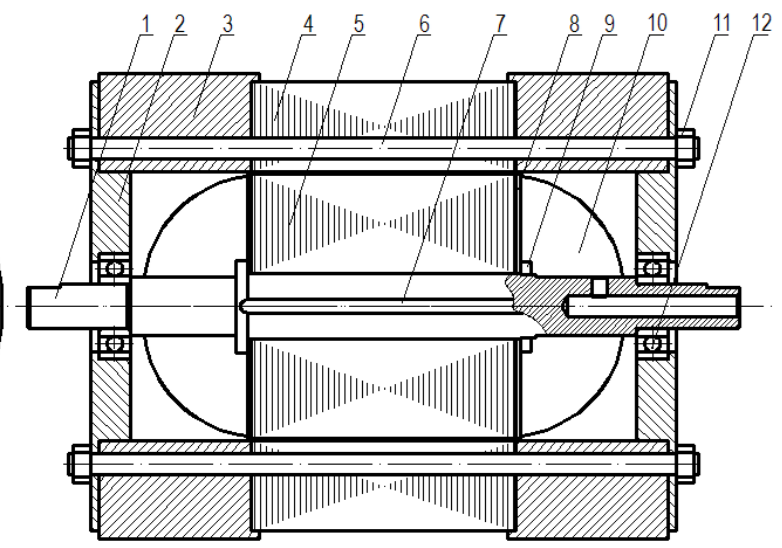

(b)

Fig. 3. SynRM model for calculations (a) and type of design (b): 1 - shaft; 2 - end shield; 3 - body; 4 - rotor core; 5 - stator core; 6 - stud-bolt; 7 - wedge; 8 - stator end sheet; 9 - V-ring; 10 - armature winding; 11 - nut;

12 - bearing.

The segmental rotor cores of SynRM are placed in the motor body by six studbolts and are relied upon the bearings within the end shield.

\section{EXPERIMENTS ON SYNCHRONOUS RELUCTANCE MOTOR MAGNETOSTATIC FIELD}

The experimental testing of electric motor aims at finding its characteristics and parameters. The angular curve of a synchronous motor, i.e. the electromagnetic torque dependence on the load angle, is one of the most important characteristics which reflects the motor's stable mode. Even without using complicated loading devices it is possible to construct a precise angular curve for the synchronous motor by powering the armature winding with DC current. According to the method for determination of static electromagnetic torque, the magnetizing force fundamental harmonic due to $\mathrm{DC}$ current at a braked rotor is to be equal to that due to $\mathrm{AC}$ current 
in the case of variable magnetic field. Feasible connection schemes for the armature winding in magnetostatic field experiments are shown in Fig. 4.

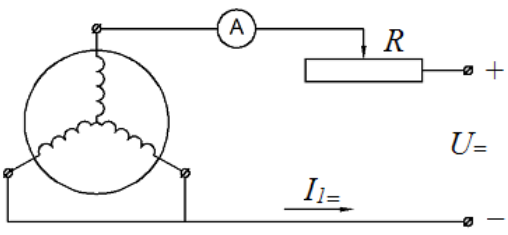

(a)

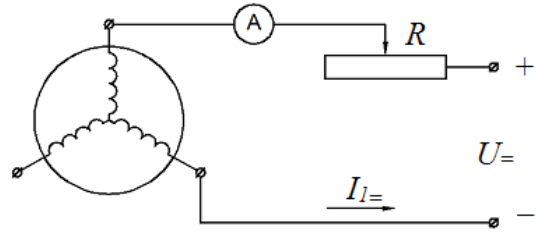

(b)

Fig. 4. Connection schemes for SynRM three-phase armature windings in experiments with braked motor rotor.

In the connection scheme of three-phase armature winding shown in Fig. $4 a$, the DC current is $I_{1=}=\sqrt{2} I_{1}$, while in the scheme of Fig. $4 b$ this value is $I_{1=}=\sqrt{3 / 2} I_{1}$. Here $I_{1}$ is the motor's AC current rated value (for more detailed information about the electromagnetic torque definition method see [11]).

Using the aforementioned method, it is possible to obtain only frontal sections of the angular curve, when the SynRM rotor has stable position. The experimentally obtained angular curves for the SynRM prototype are shown in Fig. 5.

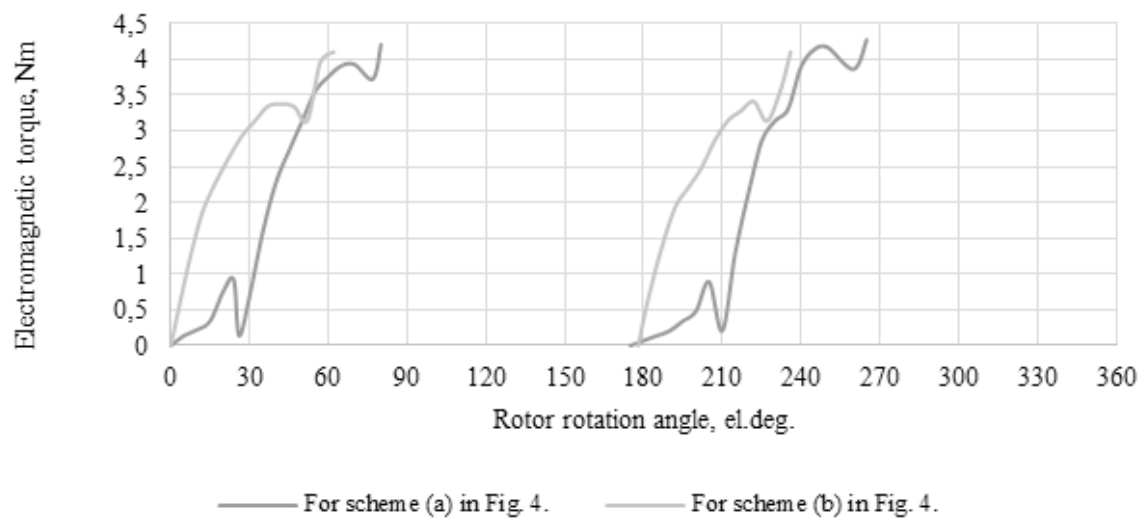

Fig. 5. SynRM angular curves for magnetostatic mode.

In the angular curves obtained for the SynRM prototype (Fig. 5) insignificant electromagnetic torque ripples can be seen. Experimental tests of the rotating motor show that these ripples, in the case when a motor achieves the rated rotational speed, do not cause any type of vibrations that would be dangerous for its normal operation.

\section{THE POTENTIAL USE OF SWITCHED RELUCTANCE MOTORS IN HAND POWER TOOLS INSTEAD OF COMMUTATOR MOTORS}

One of the main reasons for using the commutator motors in low-power equipment, especially hand-operated tools, is their wide mechanical curve spectrum. From this point of view, SynRM should be used with electronic commutation as switched reluctance motors (SRMs). 
An SRM consists of a three-phase synchronous motor, a controlled DC-AC inverter, and a rotor position sensor (direct or indirect). The controlled inverter is composed of a semiconductor switch and an inverter control unit, and ensures operating conditions for the motor. Therefore, SRM can be classified as a brushless alternative to the DC motor. However, this type motor operates in the same manner as classical synchronous motor, because rotational speeds of both the motor rotor and stator magnetic fields are the same. The main difference between SRM and a classical synchronous motor connected to the AC current system with unlimited load is that the SRM rotor rotational speed determines the stator magnetic field rotational speed through feedback.

Using the fundamental principles of synchronous machines, it is possible to consider SRM as a synchronous motor working in a specific operation mode with some parameters being constant, e.g. load angle $\theta$ between the supply voltage and the fundamental harmonic of no-load EMF, or angle $\varepsilon$ between the excitation and the armature MMF axes. In this case, feasible mechanical curves of the SRM can be constructed based on the parameters calculated for the operating mode at definite angle $\theta$ from the equation:

$$
\begin{aligned}
& T_{e m}=m p L_{a d} U^{2}\left[\omega L_{a d}\left(\frac{k_{q}}{k_{d}}+\sigma-1\right) \cos \theta-r_{1} \sin \theta\right] \times \\
& \times \frac{\left(\sigma \omega L_{a d} \sin \theta+r_{1} \cos \theta\right)\left(1-\frac{k_{q}}{k_{d}}\right)}{\left[r_{1}^{2}+\sigma \omega^{2} L_{a d}^{2}\left(\frac{k_{q}}{k_{d}}+\sigma-1\right)\right]^{2}},
\end{aligned}
$$

where the motor armature current is

$$
\begin{aligned}
& I_{1}=\frac{U \sqrt{\left(\omega L_{a d} \sigma \sin \theta+r_{1} \cos \theta\right)^{2}+}}{r_{1}^{2}+\sigma \omega^{2} L_{a d}^{2}\left(\frac{k_{q}}{k_{d}}+\sigma-1\right)} \rightarrow \\
& \rightarrow \overline{\left[\omega L_{a d}\left(\frac{k_{q}}{k_{d}}+\sigma-1\right) \cos \theta-r_{1} \sin \theta\right]^{2}},
\end{aligned}
$$

Similarly, for the operating mode at definite angle $\varepsilon$ the electromagnetic torque can be calculated using the equation:

$$
T_{e m}=\frac{1}{2} m p L_{a d} I_{1}^{2}\left(1-\frac{k_{q}}{k_{d}}\right) \sin 2 \varepsilon .
$$


In Eqs. (2-4) $T_{e m}$ is the electromagnetic torque,

$L_{a d}$ is the inductance corresponding to the armature magnetic flux along the direct axis;

$\sigma \quad$ is the distributed factor of the armature winding;

$k_{d}$ is the armature reaction factor along the direct axis;

$k_{q}$ is the armature reaction factor along the quadrature axis;

$r_{l}$ is the active resistance of the armature winding.

The angular frequency of armature current is proportional to the rotor rotational speed:

$$
n=\frac{\omega}{2 \pi p}
$$

Based on Eqs. (2)-(5), which are derived from the synchronous machine vector diagram [12], mechanical curves $n=f\left(T_{e m}\right)$ for $\mathrm{SRM}^{1}$ at operating modes with different angle $\theta$ or $\varepsilon$ values are shown in Fig. 7.

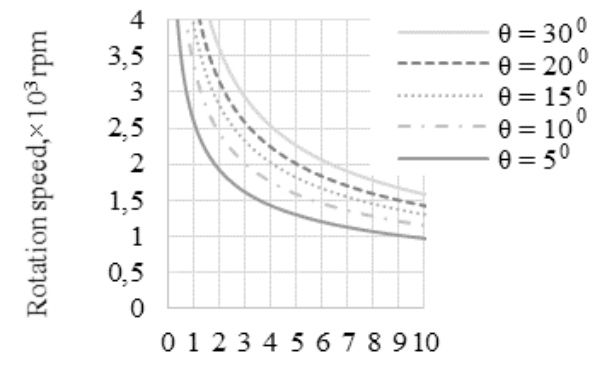

Electromagnetic torque, $\mathrm{Nm}$

(a)

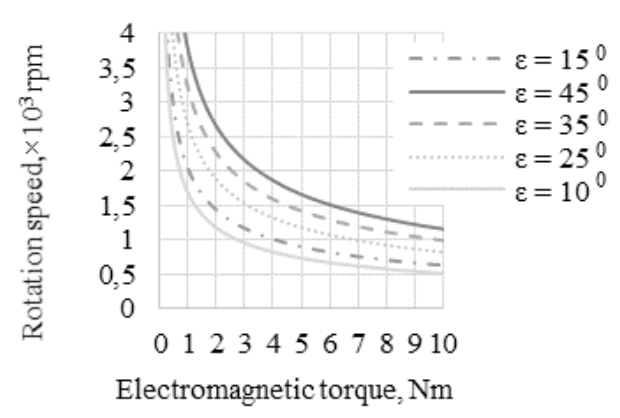

(b)

Fig. 7. Mechanical curves for SRM at different angles $\theta$ (a) and $\varepsilon$ (b).

Analysis of the obtained mechanical curves shows that in order to ensure high properties of SRM for application in hand-operated tools, angles $\theta$ or $\varepsilon$ are to be changing in dependence on the load changes. Therefore, SRM can ensure a wide spectrum of mechanical curves and compete with commutator motors that are used in low-power electrical devices.

\section{CONCLUSIONS}

Based on the results obtained in the work, the following conclusions can be drawn:

1. Synchronous reluctance motors that operate in specific modes as switched reluctance motors are highly promising for the use in low-power electrical devices and can successfully compete with the commutator motors.

\footnotetext{
${ }^{1}$ Parameters of SRM: $U_{l}=220 \mathrm{~V}, r_{l}=4.98 \Omega, L_{a d}=0.54 \mathrm{H}, \sigma=1.15, m=3, p=1, k_{q} / k_{d}=0.15$.
} 
2. To improve the SRM efficiency, the proposed new design with segmental external rotor can be used.

3. The electromagnetic torque per unit volume in a new SynRM design with segmental external rotor is about 30-40\% higher than that of the well-known SynRM prototype.

4. The method for electromagnetic torque determination of a motor having braking rotor with magnetostatic field makes it possible to easily and quickly obtain experimental results for the construction of motor angular curves without special loading devices.

\section{ACKNOWLEDGEMENTS}

This work has been supported by the State Research Programme "LATENERGI".

\section{REFERENCES}

1. Vila Mani, M. (2006). A quick overview on rotatory brush and brushless DC motors. In: Ingenia-cat - Motion Control Department (Spain): Available at: http://www.ingeniamc.com/Es/Soporte/Centro-Aprendizaje.aspx. [Accessed December $15,2014]$.

2. Reston, C. (2004). Brushed DC Motor Fundamentals. In: Microchip Technology Inc., AN905, 10 p. Available at: http://www.microchip.com. [Accessed December 15, 2014].

3. Levin, N., Kamolins, E., Vitolina, S. (2014). Brushless electric machines. Riga: RTU (in Latvian).

4. Gieras, J. F., Gieras, I. A. (2001). Recent developments in electrical motors and drives. In: $2^{\text {nd }}$ International Conference on Electrical and Electronics Engineering. Bursa, Turkey, 8 p. Available at: http://www.researchgate.net. [Accessed January 5, 2015].

5. Cho, K.Y., Yang, S.B. and Hong, C.H. (2004). Sensorless Control of a PM Synchronous Motor for Direct-Drive Washer without Rotor Position Sensors. In: Electric Power Applications. IEE Proceedings 151(1), 61-69.

6. Lelkes, A. (2002). Electronically commutated motors for fan applications. In: PCIM, Nuremberg, 1-6. Available at http://www.researchgate.net/ [Accessed December 20, 2014]

7. Dirba, J., Ketners K. (2009). Electric machines. Riga: RTU (in Latvian).

8. Lipo, T. A. (1991). Synchronous reluctance machines - a viable alternative for AC drives. In: Electric Machines and Power Systems, 659-671.

9. Pugachevs, V., Dirba, J., Kukjane, L., Levins, N., Orlova, S. (2012). Synchronous reluctance motor. Patent of the Republic of Latvia, LV 14418 B.

10. Levins, N., Pugachevs, V., Dirba, J., Lavrinovicha, L., Brakanskis, U. (2013). Synchronous reluctance motor. Patent of the Republic of Latvia. LV 14627 B.

11. Lavrinovicha, L. (2014). Design and Optimisation of Brushless Synchronous Motors for Use in Low Power Equipment. PhD Thesis. Riga: RTU (in Latvian).

12. Dirba, J. (1997). Special operation modes of synchronous machines. Riga: RTU (in Latvian). 


\title{
SINHRONO REAKTĪVO DZINĒJU IZMANTOŠANAS PERSPEKTĪVAS MAZJAUDAS ELEKTROIERİCĒS
}

\author{
J. Dirba, L. Lavrinoviča, R. Dobrijans
}

Kopsavilkums

Aplūkoti sinhronie reaktīvie dzinēji kā mazjaudas kolektordzinēju alternatīva. Analizētas sinhrono reaktīvo dzinēju uzlabotas konstrukcijas ar segmentveida ārējo rotoru. Aprakstīti sinhrono reaktīvo dzinēju vienādojumi un raksturlīkṇu aprēķināšanas metodika gadījumam, kad tie darbojas ventiḷ̂zinēju sastāvā. Parādīts, ka sinhronie reaktīvie dzinēji šādos gadījumos var nodrošināt plašu mehānisko raksturlīkṇu spektru un sekmīgi konkurēt ar kolektordzinējiem mazjaudas elektroierīcēs.

20.01.2015. 